\title{
Prolactin level in umbilical cord blood of newborn and its relation to respiratory distress syndrome
}

\author{
Namrata V. Padvi, Hemraj R. Narkhede*, Amol P. Pawar, Pravin N. Mhatre
}

Department of Obstetrics and Gynecology, Seth G S Medical College Mumbai, Maharashtra, India

Received: 08 December 2016

Accepted: 17 December 2016

\section{*Correspondence:}

Dr. Hemraj R. Narkhede,

E-mail: hemrajrn@gmail.com

Copyright: () the author(s), publisher and licensee Medip Academy. This is an open-access article distributed under the terms of the Creative Commons Attribution Non-Commercial License, which permits unrestricted non-commercial use, distribution, and reproduction in any medium, provided the original work is properly cited.

\section{ABSTRACT}

Background: Production of lower concentrations of prolactin in fetus is considered as one of the major contributor for the development of respiratory distress syndrome (RDS) in newborns considerably in pregnants with maternal complications. Hence the present study was conducted with the objective to measure the serum level of cord blood prolactin in normal pregnancy and in pregnancy with maternal complications and its association with development of RDS in newborn.

Methods: In this prospective study of 100 women, 28 with normal pregnancy (Group A) and 72 with abnormal pregnancies (Group B) were included in the study. Umbilical cord blood was collected and serum prolactin level was estimated using radio-immuno assay. The obtained values were correlated with prevalence of RDS in neonates and maternal complications.

Results: The average age of pregnant women participated in Group A was 26 years and Group B was 27 years. In Group A 2 babies with birth weight of 2001-3000 gm had a cord serum prolactin level of $216 \pm 137.8 \mathrm{ng} / \mathrm{mL}$ developed RDS. In Group B the level of prolactin was $285 \pm 276$ and $326 \pm 132 \mathrm{ng} / \mathrm{mL}$ in 4 RDS babies with birth weight of $<1000 \mathrm{gm}$ and 1000-2000 gm respectively. It was observed that cord serum prolactin levels had no correlation with the mode of delivery, sex of newborn, steroid therapy. In Group A, 2 neonates developed RDS which were of gestational age between 32-35 weeks with mean prolactin level of $216 \mathrm{ng} / \mathrm{ml}$, while in Group B, 1 neonate with gestational age less than 32 weeks and mean prolactin level of 480 and 4 neonates of 32-35 weeks with mean prolactin level of $266 \mathrm{ng} / \mathrm{mL}$ developed RDS. Out of 27 mothers with complications of PIH, 3 developed RDS. 1 case each from IUGR and twins developed RDS respectively.

Conclusions: The risk of RDS is less in newborn with high prolactin level than in newborns with low prolactin levels. So prolactin might have a role in fetal lung maturation.

Keywords: Cord serum prolactin level, Complications in pregnancy, Respiratory distress syndrome

\section{INTRODUCTION}

Respiratory distress syndrome (RDS) also known as hyaline membrane disease leading to mortality or morbidity in premature babies. It is more commonly encountered within the first 48-72 hours of life. ${ }^{1}$ In India, it has been observed that $0.7 \%$ to $8.3 \%$ of all perinatal deaths occur due to respiratory distress syndrome. It is well known that inadequate pulmonary surfactant is responsible for the development of RDS. Several hormones (estradiol, cortisol, testosterone, thyroid hormones, glucagon's, insulin) are involved in the production of lung surfactant. ${ }^{3}$ Prolactin in increasing concentration through a complex mechanism seems to participate in pulmonary maturation. ${ }^{4}$

Previous studies have shown the possible role of prolactin in the development of RDS, but they did not consider the maternal conditions which might influence the observed value. ${ }^{5,6}$ Hence this study aims to measure the serum 
level of cord blood prolactin in normal pregnancy and its association with development of RDS in newborn and to ascertain the role of maternal conditions that might influence cord blood concentration of prolactin.

\section{METHODS}

The present study was undertaken for a period of 6 months at department of obstetrics and gynecology, Seth G S Medical College, Mumbai, after approval by the Institutional ethical committee.

A prospective study of randomly selected women delivered in our hospital, included 28 pregnant women with uncomplicated pregnancy (Group A) and 72 women with complicated pregnancy (Group B). The pregnancy associated complications included were pregnancy induced hypertension (PIH), premature rupture of membranes (PROM), preterm labor (PTL), intrauterine growth restriction (IUGR), twins, gestational diabetes mellitus (GDM).

Woman with intrauterine death, malformed baby and thyroid diseases were excluded from the study. A detailed history of mothers was taken and a thorough examination was done. The mode of delivery was noted.

Sample of umbilical cord blood was obtained at delivery immediately after cord clamping in plain tube. Sample was stored under refrigeration at temp 6- $8^{\circ} \mathrm{C}$. Samples were transported to the laboratory on daily basis in an ice lined container. Test was performed by using radio immune assay. The results of obtained Serum prolactin values were noted according to gestational age groups in weeks and correlated with the neonatal outcome.

Respiratory function of the new-borns were assessed by attending neonatologist, the criteria for establishing the diagnosis of respiratory distress syndrome included the Apgar score, presence of grunting and retraction, oxygen requirement, need of ventilator or surfactant therapy and chest radiograph.

The data was tabulated and analysed using Chi-square test. The values obtained $\mathrm{p}<0.05$ was considered statistically significant.

\section{RESULTS}

A total of 100 pregnant women were included in the study with age ranging from 25 to above 35 years. The average age of pregnant women in Group A was 26 years and Group B was 27 years. Table 1 represents the number of pregnant women in two groups with respective ages. Of total 93 patients under the age group 25-35years, 6 of them gave birth to neonates having RDS and one women of age above 35 years delivered baby with RDS as shown in Table 2. The difference between the age distributions of patient with neonates developing RDS was not significant.
Table 1: Age wise distribution of study group.

\begin{tabular}{|c|c|c|c|c|}
\hline \multirow[b]{2}{*}{$\begin{array}{l}\text { Age } \\
\text { (years) }\end{array}$} & \multicolumn{2}{|c|}{ Study group } & \multirow[b]{2}{*}{ Total } & \multirow{2}{*}{$\begin{array}{l}\text { Chi- } \\
\text { Square } \\
\text { and p } \\
\text { value }\end{array}$} \\
\hline & $\begin{array}{l}\text { Group A } \\
\text { (No high } \\
\text { risk) }\end{array}$ & $\begin{array}{l}\text { Group B } \\
\text { (High } \\
\text { risk) }\end{array}$ & & \\
\hline $\begin{array}{l}\text { Up to } \\
25\end{array}$ & $11(39.3)$ & $29(40.3)$ & 40 & \multirow{4}{*}{$\begin{array}{l}0.784 ; p \\
=0.676\end{array}$} \\
\hline $\begin{array}{l}26 \text { to } \\
35\end{array}$ & $\begin{array}{l}16 \\
(57.1 \%)\end{array}$ & $37(51.4)$ & 53 & \\
\hline $\begin{array}{l}\text { Above } \\
35\end{array}$ & $1(3.6)$ & $6(8.3)$ & 7 & \\
\hline Total & 28 & 72 & 100 & \\
\hline
\end{tabular}

Table 2: Age distribution of patient with neonates developing RDS.

\begin{tabular}{|c|c|c|c|c|}
\hline \multirow[t]{2}{*}{$\begin{array}{l}\text { Age } \\
\text { (years) }\end{array}$} & \multicolumn{2}{|c|}{$\begin{array}{l}\text { No. of patients } \\
(\%) \text { with RDS }\end{array}$} & \multirow[t]{2}{*}{ Total } & \multirow[t]{2}{*}{$\begin{array}{l}\text { Chi-Square } \\
\text { and p value }\end{array}$} \\
\hline & Yes & No & & \\
\hline $\begin{array}{l}\text { Up to } \\
25\end{array}$ & $3(42.9)$ & $\begin{array}{l}37 \\
(39.8)\end{array}$ & 40 & \multirow[t]{4}{*}{$\begin{array}{l}0.732 ; \mathrm{p} \\
=0.693\end{array}$} \\
\hline $\begin{array}{l}26 \text { to } \\
35\end{array}$ & 3 (42.9) & $\begin{array}{l}50 \\
(53.8)\end{array}$ & 53 & \\
\hline $\begin{array}{l}\text { Above } \\
35\end{array}$ & $\begin{array}{l}1 \\
(14.33)\end{array}$ & $6(6.5)$ & 7 & \\
\hline Total & 7 (100) & $\begin{array}{l}93 \\
(100)\end{array}$ & 100 & \\
\hline
\end{tabular}

Table 3: Distribution of RDS according to gravity.

\begin{tabular}{|c|c|c|c|c|}
\hline \multirow[t]{2}{*}{ Gravidity } & \multicolumn{2}{|c|}{$\begin{array}{l}\text { No. of patients } \\
(\%) \text { with RDS }\end{array}$} & \multirow[t]{2}{*}{ Total } & \multirow[t]{2}{*}{$\begin{array}{l}\text { Chi-Square } \\
\text { and p value }\end{array}$} \\
\hline & Yes & No & & \\
\hline Primi & $2(28.6)$ & $\begin{array}{l}36 \\
(38.8)\end{array}$ & 38 & \multirow[t]{3}{*}{$\begin{array}{l}0.284 ; \mathrm{p} \\
=0.594\end{array}$} \\
\hline $\begin{array}{l}\text { Multi } \\
\text { Gravida }\end{array}$ & $5(71.4)$ & $\begin{array}{l}57 \\
(61.3)\end{array}$ & 62 & \\
\hline Total & 7 (100) & $\begin{array}{l}93 \\
(100)\end{array}$ & 100 & \\
\hline
\end{tabular}

Table 4: Distribution of RDS according to gestational age.

\begin{tabular}{|c|c|c|c|c|}
\hline \multirow{2}{*}{$\begin{array}{l}\text { Weeks } \\
\text { of } \\
\text { gestation }\end{array}$} & \multicolumn{2}{|c|}{$\begin{array}{l}\text { No. of patients } \\
(\%) \text { with RDS }\end{array}$} & \multirow[t]{2}{*}{ Total } & \multirow[t]{2}{*}{$\begin{array}{l}\text { Chi-Square } \\
\text { and p value }\end{array}$} \\
\hline & Yes & No & & \\
\hline $\begin{array}{l}\text { Up to } 32 \\
\text { weeks }\end{array}$ & $\begin{array}{l}1 \\
(14.3)\end{array}$ & $2(2.2)$ & 3 & \multirow[t]{5}{*}{$\begin{array}{l}34.460 ; p \\
\text { value }<0.001\end{array}$} \\
\hline $\begin{array}{l}32.1 \text { to } \\
35 \text { weeks }\end{array}$ & $\begin{array}{l}6 \\
(85.7)\end{array}$ & $9(9.7)$ & 15 & \\
\hline $\begin{array}{l}35.1 \text { to } \\
37 \text { weeks }\end{array}$ & 0 & $\begin{array}{l}22 \\
(23.7)\end{array}$ & 22 & \\
\hline $\begin{array}{l}\text { Above } \\
37.1 \\
\text { weeks }\end{array}$ & 0 & $\begin{array}{l}60 \\
(64.5)\end{array}$ & 60 & \\
\hline Total & $\begin{array}{l}7 \\
(100)\end{array}$ & $\begin{array}{l}93 \\
(100)\end{array}$ & 100 & \\
\hline
\end{tabular}


Table 5: Distribution of patient according to cord prolactin levels with gestational age.

\begin{tabular}{|c|c|c|c|c|c|c|}
\hline \multirow{3}{*}{ Weeks of gestation } & \multicolumn{6}{|c|}{ Cord serum prolactin levels } \\
\hline & \multicolumn{3}{|c|}{ Group A (No high risk) } & \multicolumn{3}{|c|}{ Group B (High risk) } \\
\hline & $\mathrm{N}$ & Mean & Std Dev & $\mathrm{N}$ & Mean & Std Dev \\
\hline Up to 32 weeks & 1 & 408.00 & 0 & 2 & 390.50 & 126.57 \\
\hline 32.1 to 35 weeks & 4 & 232.75 & 81.58 & 11 & 324.45 & 285.86 \\
\hline 35.1 to 37 weeks & 4 & 183.00 & 114.20 & 18 & 263.83 & 169.80 \\
\hline Above 37.1 weeks & 19 & 377.32 & 136.14 & 41 & 313.63 & 167.03 \\
\hline
\end{tabular}

Table 3 shows the non-significant distribution of RDS according to gravidity. Of total 100 pregnant women 38 were primagravidas and 2 of them delivered babies with RDS, while remaining 62 were multigravidas and 5 of them parturated babies with RDS. Out of 100, 7 babies born with RDS at a gestational age group ranging from 32- 35 weeks as given in Table 4 . Table 5 presents the distribution of babies according to cord prolactin levels with different gestaional ages in both the groups. Only 1 RDS baby was born in Group B at a gestational age of 32 weeks with a prolactin level of $480 \mathrm{ng} / \mathrm{mL}$ and the prolactin level in neonates born at a gestational age of 32 35 weeks in Group A was $216 \pm 137.8 \mathrm{ng} / \mathrm{mL}$ and Group B was $266.75 \pm 160.2 \mathrm{ng} / \mathrm{mL}$.
Table 6: Correlation of birth weight with RDS.

\begin{tabular}{|c|c|c|c|c|}
\hline \multirow{2}{*}{$\begin{array}{l}\text { Birth } \\
\text { weight }\end{array}$} & \multicolumn{2}{|c|}{$\begin{array}{l}\text { No. of patients } \\
\text { (\%) with RDS }\end{array}$} & \multirow[t]{2}{*}{ Total } & \multirow{2}{*}{$\begin{array}{l}\text { Chi-Square } \\
\text { value and p } \\
\text { value }\end{array}$} \\
\hline & Yes & No & & \\
\hline $\begin{array}{l}\text { Less than } \\
1000 \mathrm{gm}\end{array}$ & $2(28.6)$ & $2(2.2)$ & 4 & \multirow{5}{*}{$\begin{array}{l}16.539 ; \mathrm{p} \\
<0.001\end{array}$} \\
\hline $\begin{array}{l}1001 \text { to } \\
2000 \mathrm{gm}\end{array}$ & $3(42.9)$ & $\begin{array}{l}15 \\
(16.1)\end{array}$ & 18 & \\
\hline $\begin{array}{l}2001 \text { to } \\
3000 \mathrm{gm}\end{array}$ & $\begin{array}{l}2 \\
(28.6)\end{array}$ & $\begin{array}{l}58 \\
(62.4)\end{array}$ & 60 & \\
\hline $\begin{array}{l}\text { More } \\
\text { than } 3 \mathrm{~kg}\end{array}$ & 0 & $\begin{array}{l}18 \\
(19.4)\end{array}$ & 18 & \\
\hline Total & 7 (100) & $\begin{array}{l}93 \\
(100)\end{array}$ & 100 & \\
\hline
\end{tabular}

Table 7: Distribution of birth weight with relation to cord serum prolactin level and RDS occurrence.

\begin{tabular}{|c|c|c|c|c|c|c|c|c|c|c|c|c|}
\hline \multirow{3}{*}{ Birth weight } & \multicolumn{12}{|c|}{ Cord serum prolactin levels } \\
\hline & \multicolumn{3}{|c|}{$\begin{array}{l}\text { Group A (no high risk) } \\
\text { RDS }\end{array}$} & \multicolumn{3}{|c|}{$\begin{array}{l}\text { Group B (high risk) } \\
\text { RDS }\end{array}$} & \multicolumn{3}{|c|}{$\begin{array}{l}\text { Group A (no high risk) } \\
\text { RDS }\end{array}$} & \multicolumn{3}{|c|}{$\begin{array}{l}\text { Group B (high risk) } \\
\text { RDS }\end{array}$} \\
\hline & $\mathrm{N}$ & Mean & Std & $\mathrm{N}$ & Mean & Std & $\mathrm{N}$ & Mean & Std & $\mathrm{N}$ & Mean & Std \\
\hline$<1000 \mathrm{gm}$ & 0 & 0 & 0 & 1 & 408 & 0 & 2 & 285 & 276 & 1 & 301 & 0 \\
\hline $1001-2000 \mathrm{gm}$ & 0 & 0 & 0 & 4 & 169 & 98 & 3 & 326 & 132 & 00 & 249 & 208 \\
\hline $2001-3000 \mathrm{gm}$ & 2 & 216 & 137 & 15 & 393 & 144 & 0 & 0 & 0 & 43 & 309 & 182 \\
\hline$>3 \mathrm{~kg}$ & 0 & 0 & 0 & 6 & 3040 & 72 & 0 & 0 & 0 & 12 & 339 & 214 \\
\hline
\end{tabular}

Table 8: Mode of delivery and its correlation with RDS.

\begin{tabular}{|c|c|c|c|c|}
\hline \multirow{2}{*}{$\begin{array}{l}\text { Mode of } \\
\text { delivery }\end{array}$} & \multicolumn{2}{|c|}{$\begin{array}{l}\text { No. of patients } \\
\text { (\%) with RDS }\end{array}$} & \multirow[t]{2}{*}{ Total } & \multirow{2}{*}{$\begin{array}{l}\text { Chi-square } \\
\text { and p value }\end{array}$} \\
\hline & Yes & No & & \\
\hline Forceps & 0 & $3(3.2)$ & 3 & \multirow{6}{*}{$\begin{array}{l}13.718 ; p \\
=0.008\end{array}$} \\
\hline FTND & 0 & $\begin{array}{l}25 \\
(26.9)\end{array}$ & 25 & \\
\hline LSCS & $4(57.1)$ & $\begin{array}{l}58 \\
(62.4)\end{array}$ & 62 & \\
\hline PTVD & $3(42.9)$ & $5(5.4)$ & 8 & \\
\hline Vacuum & 0 & $2(2.2)$ & 2 & \\
\hline Total & 7 (100) & $93(100)$ & 100 & \\
\hline
\end{tabular}

Prolactin levels were directly proportional to the birth weight in both the groups. In Group A 2 babies with birth weight of 2001-3000 gm had a cord serum prolactin level of $216 \pm 137.8 \mathrm{ng} / \mathrm{mL}$ developed RDS as shown in Table 6 and 7 , whereas in Group B the level of prolactin was $285 \pm 276$ and $326 \pm 132 \mathrm{ng} / \mathrm{mL}$ in 4 RDS babies with birth weight of $<1000 \mathrm{gm}$ and 1000-2000 gm respectively.

Cord serum prolactin levels had no correlation with the mode of delivery. In all 62 were born by caesarean section, and 8 by PTVD and of these 7 had RDS as given in Table 8. From the results of Table 9 it is evident that there is a correlation between sex of newborn and RDS. 
The prevalence of RDS is more in males compared to females but the difference is non-significant.

Table 9: Occurrence of RDS in relation to sex of newborn.

\begin{tabular}{|lllll|}
\multirow{2}{*}{ Sex } & \multicolumn{2}{l}{$\begin{array}{l}\text { No. of patients } \\
(\%) \text { with RDS }\end{array}$} & Total & $\begin{array}{l}\text { Chi- } \\
\text { Square } \\
\text { and p } \\
\text { value }\end{array}$ \\
\cline { 1 - 4 } Yes & No & $\begin{array}{l}\text { 1.138; } \mathrm{p} \\
=0.286\end{array}$ \\
\cline { 1 - 4 } Female & $2(28.6)$ & $\begin{array}{l}46 \\
(49.5)\end{array}$ & 52 & \\
\hline Total & $7(100)$ & $93(100)$ & 100 & \\
\hline
\end{tabular}

Table 10: Comparison of RDS between steroids treated and untreated.

\begin{tabular}{|llll|}
\hline Steroid & \multicolumn{2}{l}{ No. of patients (\%) with } & Total \\
& RDS & Nes & \\
\hline Given & $3(42.9)$ & $8(24.2)$ & 11 \\
\hline Not given & $4(57.1)$ & $25(75.8)$ & 29 \\
\hline Total & $7(17.5)$ & $33(82.5)$ & 40 \\
\hline
\end{tabular}

Table 11: Correlation in occurrence of RDS in maternal complications.

\begin{tabular}{|c|c|c|c|c|}
\hline \multirow{2}{*}{$\begin{array}{l}\text { Maternal } \\
\text { complications }\end{array}$} & \multicolumn{2}{|c|}{$\begin{array}{l}\text { No. of patients } \\
(\%) \text { RDS }\end{array}$} & \multirow[t]{2}{*}{ Total } & \multirow{2}{*}{$\begin{array}{l}\text { Chi- } \\
\text { Square } \\
\text { and p } \\
\text { value }\end{array}$} \\
\hline & Yes & No & & \\
\hline PIH & $\begin{array}{l}3 \\
(42.9)\end{array}$ & $\begin{array}{l}24 \\
(25.8)\end{array}$ & 27 & \multirow{2}{*}{$\begin{array}{l}0.960 ; \mathrm{P} \\
=0.327\end{array}$} \\
\hline No PIH & $\begin{array}{l}4 \\
(57.1)\end{array}$ & $\begin{array}{l}69 \\
(74.2)\end{array}$ & 73 & \\
\hline GDM & 0 & $\begin{array}{l}24 \\
(25.8)\end{array}$ & 24 & \multirow{2}{*}{$\begin{array}{l}2.377 ; \mathrm{P} \\
=0.123\end{array}$} \\
\hline No GDM & 7 (100) & $\begin{array}{l}69 \\
(74.2)\end{array}$ & 76 & \\
\hline IUGR & $\begin{array}{l}1 \\
(14.3)\end{array}$ & $\begin{array}{l}18 \\
(19.4)\end{array}$ & 19 & \multirow{2}{*}{$\begin{array}{l}0.109 ; \mathrm{P} \\
=0.742\end{array}$} \\
\hline No IUGR & $\begin{array}{l}6 \\
(85.7) \\
\end{array}$ & $\begin{array}{l}75 \\
(80.6)\end{array}$ & 81 & \\
\hline Twins & $\begin{array}{l}1 \\
(14.3)\end{array}$ & $1(1.1)$ & 2 & \multirow{2}{*}{$\begin{array}{l}5.796 ; \mathrm{P} \\
=0.016\end{array}$} \\
\hline No twins & $\begin{array}{l}6 \\
(85.7) \\
\end{array}$ & $\begin{array}{l}92 \\
(98.9)\end{array}$ & 98 & \\
\hline
\end{tabular}

In our study forty women (42 babies) with Group A and Group B, pregnancy were admitted with premature labor or required to be delivered prematurely. Only 11 women (12 babies) received steroid for lung maturation as in Table 10. Of these 12 babies, 3 babies developed RDS, while 8 did not develop RDS .In women who did not have steroid, 2 babies developed RDS. In Group A out of
28 neonates 2 neonates developed RDS with mean prolactin level of $330 \mathrm{ng} / \mathrm{mL}$ while 5 neonates from Group B with mean prolactin level of $305 \mathrm{ng} / \mathrm{mL}$ developed RDS. We could not find statistical significance because of less sample size.

From Table 11 it is evident that no significant association was existed between RDS and complications in pregnancy. RDS was observed more in number in neonates who was born from mothers having PIH. Out 18 cases of IUGR 1 developed RDS and out of 2 cases of twins 1 case had shown RDS in newborns.

\section{DISCUSSION}

Prolactin, apart from its other actions, is thought to play some role in lung surfactant development. Even normally also during pregnancy, prolactin levels increase gradually from non-pregnant levels of $10-20 \mathrm{ng} / \mathrm{mL}$ to $200-400$ $\mathrm{ng} / \mathrm{mL}$ at term. But this rise is lower if the woman develops some pregnancy related complication. ${ }^{7}$

In our study, there are total 40 patients who are up to the age 25 years, out of which 11 are of Group A, 29 are from Group B. Then total 53 are of age group 26-35 years, out of which 16 are from Group A, 37 from Group B. While total 7 patients are above 35 years of age, among which 1are from Group A, 6 are from Group B. the average age of females included in Group $A$ is 26 years while that in Group B is 27 years. The youngest mother is 19 years old while the oldest one is of 41 years age. As the patients from both groups have same average age, both groups are comparable. In those patients who developed RDS 3 neonates were born to women up to 25 years age, 3 neonates for 26-35 years age and 1 for pregnant above 35 years age and explains that no significant correlation existed between maternal age and development of RDS. In our study we could not find the significant correlation between RDS and Gravidity.

In group A, out of the 28 newborns 2 developed RDS and in group B, out of the 72 newborns 5 developed RDS. Thus, an inverse relationship is observed between the incidences of RDS and gestational age irrespective of normal pregnancy (Group A) and pregnancy with high risk (Group B). This is according to the well-known fact that RDS is more common among the preterm infants due to immaturity of type II pneumocytes. These observations are in accordance with the observations of Patil et al. ${ }^{6}$

It is seen in many studies that prolactin level increases as the gestational age advances. ${ }^{3}$ In our studies we have found that in Group A, with increase in gestation from 32-37 weeks to 37-40 weeks, prolactin levels increased steadily from $232.75 \pm 81.58$ to $377.32 \pm 136.14 \mathrm{ng} / \mathrm{mL}$. In Group B there is no rise but fall in level of Prolactin from $390 \pm 126.57$ to $263.83 \pm 169.80$ in gestational group from 32 weeks to 37 weeks. It has been studied that women with complicated pregnancies achieved significantly lower levels $(313.63 \pm 167.03$ vs. $377.32 \pm 136.14 \mathrm{ng} / \mathrm{mL})$ as 
compared to women without any complications but we could not find the statistical correlation in our study. In Group A, 2 neonates developed RDS which were of gestational age between 32-35 weeks with mean prolactin level of $216 \mathrm{ng} / \mathrm{mL}$, while in Group B, 1 neonate with gestational age less than 32 weeks and mean prolactin level of 480 and 4 neonates of 32-35 weeks with mean prolactin level of $266 \mathrm{ng} / \mathrm{mL}$ developed RDS. The relationship of prolactin in cord blood, gestational age and respiratory compliance after birth in newborns was explained by Schober et al. They studied a total of 36 neonates and observed that lung maturation is directly proportional to the gestational age. This study also showed that prolactin may or may not directly influence lung maturation but is definitely associated with gestational age. ${ }^{8}$

From the results it was observed that among 4 neonates with birth weight less than $1 \mathrm{~kg}, 1$ neonate from Group A with mean prolactin level of $408 \mathrm{ng} / \mathrm{mL}$ developed RDS, while 2 out of 3 neonates from Group B with mean prolactin level of $285 \mathrm{ng} / \mathrm{mL}$ developed RDS, this proves that there is a significant correlation between birth weight and RDS.

In our study we could not find significant correlation between birth weight and prolactin level in occurrence of RDS, probably because of small study sample. Out of 7 neonates who developed RDS, 2 neonates were of less than $1 \mathrm{~kg}$ birth weight with mean prolactin level of 285 $\mathrm{ng} / \mathrm{mL}, 3$ neonates were of birth weight between $1-2 \mathrm{~kg}$ with mean prolactin level of $326 \mathrm{ng} / \mathrm{mL}$ and 2 neonates between birth weight $2-3 \mathrm{~kg}$ with mean prolactin level of $216 \mathrm{ng} / \mathrm{mL}$. In contrast to these findings a positive correlation between birthweight and prolactin levels was observed in the previous studies of Promila et al, Patil et al and Dayal et al. 3,6,7

In our study, mode of delivery had no effect on cord serum prolactin levels. They were found to be directly proportional to birth weight in both normal and abnormal gestations. Leurti et al also report the same. ${ }^{9}$ But there existed a significant correlation between mode of delivery and development of RDS. Out of 100, among the 7 neonate who developed RDS, $4(57.1 \%)$ delivered by LSCS which shows the significant correlation.

Percentage of babies with RDS in steroid and non-steroid group was almost same and there was no significant difference prolactin level in these two groups. In our study only 11 women (12 babies) received steroid for lung maturation. Of these, 3 babies developed RDS. In women who did not have steroid, 2 babies developed RDS. Our observation correlates with that done by other investigators. . $^{6} 10$

In the present study, it is observed that, in mother with $\mathrm{PIH}, 3$ neonates accounting for nearly $42.9 \%$ of the total 27 neonates with mean prolactin level of $374 \mathrm{ng} / \mathrm{mL}$ developed RDS and we could not find the statistical correlation between pregnancy induced hypertension and prolactin level hence large no of sample requires for further study.

The growth restricted neonates have underdeveloped lungs and are deficient in serum cortisol and prolactin at birth, so they have greater risk of developing RDS. It is observed that 1 IUGR baby of the total 7 with mean prolactin level of $253 \mathrm{ng} / \mathrm{mL}$ developed RDS. This association is statistically not significant. It may require larger sampling size for further conclusion. Out of 2 twins involved in this study, 1 twin developed RDS. Our finding in babies with twins, correlates with Promila et al. ${ }^{3}$

The mean cord prolactin in the infants with RDS was 140 $\mathrm{ng} / \mathrm{mL}$, whereas in the healthy infant it was $276.4 \mathrm{ng} / \mathrm{mL}$. Cord prolactin levels less than $140 \mathrm{ng} / \mathrm{mL}$ were associated with high incidence of respiratory distress syndrome. While in our study it was observed that cord prolactin levels less than $200 \mathrm{ng} / \mathrm{mL}$ were characterized by high incidence of respiratory distress syndrome. ${ }^{11}$

\section{CONCLUSION}

This was a pilot study and it is a small endeavour in predicting the reliability of occurrence of RDS with only one single parameter i.e. serum cord prolactin level. It is cost effective and may be helpful in reducing delay in the initiation of the treatment of RDS and hence reducing the morbidity and mortality in neonatal age group. Prolactin has got a definite correlation with obstetric high risk factors, which we could not find because of less number of cases. But for reliable results further study with adequate sample size is required.

Funding: No funding sources

Conflict of interest: None declared

Ethical approval: The study was approved by the Institutional Ethics Committee

\section{REFERENCES}

1. Islam AKS, Bora R, Paul N, Ramasamy S. Pattern of Respiratory Problems in Neonates in a Level III Neonatal Care Unit with Special Reference to Pneumonia. Indian J Neonatal Med Res. 2016; 4(4):1-5.

2. Kumar A, Bhat BV. Respiratory distress in newborn. Indian J Maternal Child Health. 1996;7(1)8-10.

3. Promila J, Daljit S, Anupama G. Fetal cord serum prolactin level in normal and abnormal pregnancies. J Obstet Gynecol India, 2005;55(5):419-23.

4. Garcia Leon JF, Garza Fernandez L, von der Meden Alarcon JW. Analysis of the predictor value of prolactin concentration in the umbilical cord as an evaluation parameter for respiratory insufficiency in the newborn. Ginecol Obstet Mex. 1995;63:372-6.

5. Dhanireddy R, Smith YF, Hamosh M, Mullon DK, Scanlon JW, Hamosh P. Respiratory Distress 
Syndrome in the Newborn: Relationship to Serum Prolactin, Thyroxine, and Sex. Neonatology. 1983;43:1-2.

6. Patil B, Malkar V, Karale V, Madhuri U, Patil S. Foetal Cord Serum Prolactin: Levels and Association in Complications of pregnancy and Respiratory Distress Syndrome (RDS). Int J Biomed Res. 2016;7(5):256-9.

7. Dayal M, Malhotra K, Mukherjee K, Verma M. Fetal cord prolactin in normal and abnormal pregnancies. J Obstet Gynecol India. 2001;51:86-9.

8. Simbrurner S. The relationship of prolactin in cord blood, gestational age and respiratory compliances after birth in newborn infant. J Perinat Mod.1982: 10(1):23-6.

9. Leurti M, Parazzini F, Agarossi A, Bianchi C, Rocchetti M, Bevilacqua G. Risk factors for respiratory distress syndrome in the newborn. A multicentric Italian survey. Study Group for Lung Maturity of the Italian society of Perinatal Medicine. Acta Obstet Gynecol Scand. 1993;72:359-64.

10. Tolino A, de Conciflis B, Romano L, Graziano E. Fetal prolactin, levels and. respiratory distress syndrome. Clin Exp Obstet Gynecol. 1983;10(4):198-200.

11. Smith YF, Mullon DK, Hamosh M, Scanlon JW, Hamosh P. Serum Prolactin and Respiratory Distress Syndrome in the newborn. Paediatr Res. 1980;14(2):93-5.

Cite this article as: Padvi NV, Narkhede HR, Pawar AP, Mhatre PN. Prolactin level in umbilical cord blood of newborn and its relation to respiratory distress syndrome. Int J Reprod Contracept Obstet Gynecol 2017;6:433-8. 